S. I. CONCILIAR TRINITARIANISM

DOI: https://doi.org/10.14428/thl.v4i2.52323

\title{
Trinity, Subordination, and Heresy: A Reply to Mark Edwards
}

\author{
R. T. MULLINS \\ University of Edinburgh \\ rtmullins@gmail.com
}

\begin{abstract}
In this article, I offer some analytic reflections on Mark Edward's paper, "Is Subordinationism a Heresy?" I shall discuss the desiderata for a conciliar Trinitarian theology, the divine essence, and the different notions of subordination that Edwards identifies. Then I shall consider two arguments that certain accepted, conciliar notions of subordination lead to heretical notions of subordination. Thus raising the worry that conciliar Trinitarian theology might involve some internal incoherence between the homoousios doctrine and the subordination of the Son and Holy Spirit to the Father.
\end{abstract}

Keywords: Trinity, subordination, eternal generation, analytic theology

Mark Edwards has provided us with an excellent overview of the different notions of Trinitarian subordination throughout parts of church history. Some readers will be surprised to find that certain notions of subordination are affirmed in conciliar Trinitarian thought, whilst others are not. I for one greatly appreciate the clarity that Edwards brings to this issue in his essay. His essay is not intended to be historically exhaustive, but rather offers snapshots into different time periods. Edwards starts his survey with the biblical material before moving on to the debates leading up to the Council of Nicaea, and the continuation of those debates in the aftermath of the Council. After this, Edwards takes a glance at the Protestant Reformation, and then offers an interesting discussion of the Trinitarian thought of John Milton, Ralph Cudworth, and George Bull. In this reply, I wish to offer some analytic reflections on the desiderata for a conciliar Trinitarian theology, the divine essence, and the different notions of subordination that Edwards identifies. Then I shall consider two arguments that certain accepted, conciliar notions of subordination lead to heretical notions of subordination. Thus, raising the worry that conciliar Trinitarian theology might involve some internal incoherence between the homoousios doctrine and the subordination of the Son and Holy Spirit to the Father. 


\section{Conciliar Trinitarian Desiderata}

I begin my reflections with what analytic theologians typically take to be the basic Trinitarian desiderata that are contained within the conciliar documents. There are several desiderata that are necessary for constructing the doctrine of the Trinity. The basic claim of this doctrine is that the Christian God is three persons in one essence. This can be broken down into four desiderata:

T1) There are three divine persons.

T2) The divine persons are not numerically identical to each other.

T3) Homoousios: The divine persons share the same divine essence.

T4) Monotheism: The divine persons are related in such a way that there is only one God, and not three Gods.

I take these 4 desiderata to be common among Trinitarians of various stripes in the contemporary analytic discussions. ${ }^{1}$ However, this special issue is focused on developing analytic approaches to conciliar Trinitarian theology, which means that the Trinitarian desiderata must include all of the major elements of the ecumenical councils that pertain to the doctrine of the Trinity. There is one major element missing from this list-the subordination of the Son and Holy Spirit to the Father

The suggestion that subordination should be included into the conciliar Trinitarian desiderata will be difficult for some to accept. Typically, subordinationism is something that contemporary analytic theologians wish to avoid. This is because subordination comes with connotations of Arianism. However, as Mark Edwards points out, there are different kinds of subordinationism within the history of Trinitarian thought. Some of these kinds are accepted within the conciliar teachings whilst others are not. In section §3, I shall discuss Edward's different notions of subordination. For now, I will state the additional desiderata as follows.

T5) Subordination: The Son and Holy Spirit are subordinate to the Father.

There are two worries that I shall reflect on in later sections of this paper. First, it will be necessary to articulate the kind of subordination in view that is affirmed by the councils. Second, it will be necessary to consider if this kind of subordination is consistent with (T3). In order to address these worries, I will first need to unpack the divine essence in more detail.

\footnotetext{
${ }^{1}$ For a sampling of analytic discussions on the Trinity, see McCall and Rea (2009).
} 


\section{The Divine Essence}

The homoousios doctrine of (T3) states that the divine persons all share the same divine essence. In order to state that the persons have the same essence, one will need to state what the essential properties are for divinity. Here is one area where analytic theology can help fill in the details of a conciliar Trinitarian theology by drawing on the method of perfect being theology. Perfect being theology is an ancient method for thinking about the nature of God that predates Christianity. It is grounded in the intuition that God must be the source of all the perfections that one finds in the created order. The method has been developed further by classical Christian thinkers like Augustine and Anselm (cf. Wierenga 2011). Clarifying the method has been a point of interest in contemporary analytic thought (cf. Leftow 2011). The method has been used to defend both classical and non-classical conceptions of God. ${ }^{2}$ Thus providing a fruitful source for reflections and debates on the divine nature.

Perfect being theology starts by defining God as perfect, or the greatest metaphysically possible being. It offers an analysis of what it means to be the greatest possible being, and then provides a few simple steps for discerning which essential properties the greatest possible being has (cf. Speaks 2018, 8-18). The first question for a perfect being theologian to ask is this. What does it mean for God to be the greatest metaphysically possible being? In order to answer this question, I need to introduce three concepts: great-making properties, extensive superiority, and intensive superiority. ${ }^{3}$

I shall begin with great-making properties. Yujin Nagasawa says that some property $p$ is a great-making property if, all else being equal, it contributes to the intrinsic greatness of its possessor (cf. Nagasawa 2017, 53-55). Often times, philosophers and theologians state this as any property that it is intrinsically better to have than not have. A great-making property is an intrinsic property that would improve the greatness of any being that has it, and it would not worsen the greatness of any being that possesses it (cf. Nagasawa 2017, 65). Perfect being theologians emphasize that great-making properties cannot entail any liabilities or imperfections.

When it comes to discerning which properties God has essentially, the perfect being theologian will say that God has whatever properties are intrinsically better to have than not have. Part of the method of perfect being theology is to identify these great-making properties, and predicate them of God. A common

\footnotetext{
${ }^{2}$ Cf. Rogers and Hasker (2011); Rogers (2000); Richards (2003).

${ }^{3}$ I use property-talk throughout the discussion in a metaphysically neutral sense. One can speak of predicates, attributes, or something else instead, depending on one's overall metaphysics and model of God.
} 


\section{R. T. MULLINS}

list of great-making properties includes existence, power, knowledge, goodness, and freedom. However, there is more at play in the method of perfect being theology.

Merely identifying a list of potential great-making properties is not enough to establish that God is the greatest metaphysically possible being. To be the greatest metaphysically possible being is to have extensive superiority and intensive superiority to all other possible beings.

A being $x$ is extensively superior to some being $y$ if and only if $x$ has all of the same great-making properties as $y$, and $x$ has some great-making properties that $y$ does not have (cf. Nagasawa 2017, 56). In the case of God, perfect being theologians say that God has all of the possible great-making properties, and is thus extensively superior to all other possible beings.

Extensive superiority focuses on the possession of multiple great-making properties, whereas intensive superiority focuses on the intensity of the greatmaking properties. Nagasawa says that some being $x$ is intensively superior to some being $y$ if and only if $x$ has some great-making property that $y$ has, but to a greater degree of intensity than $y$ (cf. Nagasawa 2017, 57). In the case of God, perfect being theologians claim that God has all of His degreed great-making properties to the maximal degree of intensity. I say "degreed properties" because some great-making properties do not obviously come in degrees of intensity. For instance, properties like existence and eternality are traditionally taken to be greatmaking properties, but they do not obviously have degrees of intensity in which they can be possessed.

With this in mind, I can return to the homoousios doctrine. What does it mean for the three persons to share the same essence? At minimum, in order to share the same essence, all three divine persons will have to be extensively and intensively equal to each other, and extensively and intensively superior to all other beings. I say "at minimum" because there are more claims that Trinitarians can make in order to secure homoousios such as making the divine persons one simple substance, or making the divine persons constituted by the same substance, or making the divine persons essentially perichoretically related to one another. My main concern in this paper is with the minimal claim. Call it Minimal Homoousios.

Minimal Homoousios: The three divine persons are (i) extensively and intensively equal to each other, and (ii) extensively and intensively superior to all other beings.

Allow me to unpack this definition. Condition (ii) captures the notion that the divine persons are the metaphysically greatest. Condition (i) captures the notion that they have the same essence. This is because the divine persons each have the essential properties for divinity, and have them to the same degree of intensity. 
Whatever those great-making properties are, the Father, Son, and Holy Spirit will each have them. If the Father has a great-making property that the Son and Holy Spirit lack, then the Father will be extensively superior to the Son and Holy Spirit. Thus, violating the minimal homoousios. If the Father has a great-making property to a greater degree of intensity than the Son and Holy Spirit, the Father will be intensively superior, thus violating the minimal homoousios. Hence, in order to satisfy the minimal homoousios, the Father, Son, and Holy Spirit must be extensively and intensively equal.

With this discussion of the divine essence before us, I wish to turn my attention to desiderata (T5), which says that the Son and Holy Spirit are subordinate to the Father. Is there a kind of subordination that is consistent with minimal homoousios?

\section{Four Kinds of Subordination}

Edwards identifies 4 different kinds of subordination within Trinitarian thought: ontological, aetiological, axiological, and economic (cf. Edwards 2020, 69-70). Each one focuses on a different way in which the Son and Holy Spirit are subordinate to God the Father. As I shall explain in due course, some of these types of subordination are affirmed by conciliar theology whilst others are not. Before discussing which are conciliar and which are heresy, it will be best to define these terms. I start by defining the terms as Edwards does. Then I shall try to nuance and tighten up the definitions as best as I can for the purposes of doing constructive work in analytic conciliar Trinitarian theology.

For ease of exposition, Edwards focuses on the relation between the Father and the Son. According to Edwards, a subordination will be "ontological when it ascribes to the Son a substance, nature, or essence which is inferior to the Father's" (Ibid.). The subordination will be "aetiological when it asserts the Son's posteriority in the order of causation." The Son's subordination will be "axiological when it degrades him in rank or status without denying his equality in nature." And finally, the Son's subordination will be "economic when it dates the subservience of the Son to the Father from some point after his origin, most commonly from his voluntary assumption of human nature" (Ibid.).

I believe that Edwards' taxonomy accurately tracks different concepts in the history of Trinitarian thought. In what follows, I shall offer some of my own analytic reflections on these kinds of subordination in order to tighten up the definitions, and fill out the concepts. I will start with ontological subordination. I shall define it as follows.

Ontological Subordination: The Son is subordinate to the Father in that the Son has an essence which is inferior to the Father's. 


\section{R. T. MULLINS}

Ontological subordination is a kind of subordination ruled out by the Council of Nicaea because it would violate the homoousios doctrine. What would it look like for the Son to be ontologically subordinate to the Father? As I understand it, there are at least two ways for the Son to be ontologically subordinate to the Father. In each case, the Son would not have the same essence as the Father because the Son would be a distinct, and lesser being. First, the Son could be intensively inferior to the Father. Perhaps the Son is less knowledgeable than the Father. In order to build a case for this, one might point out that the Son is ignorant of certain things that only the Father knows (e.g. Matthew 24:36).

Second, the Son could be extensively inferior to the Father. In this instance, one would be saying that the Son lacks one or more essential great-making properties for divinity. For example, if the Son lacked the property of eternality, the Son would have a different essence than the eternal Father. In which case, the Son would be ontologically subordinate to the Father. An example of this is the old Arian slogan, "There was a time when the Son was not."

As noted already, ontological subordination is denied in conciliar Trinitarian theology. Yet, the next kind of subordination is affirmed by orthodox and heretic alike. This is aetiological subordination. I define it as follows.

Aetiological Subordination: The Son is subordinate to the Father in that the Son is caused to exist by the Father.

As Edwards points out, the Council of Nicaea affirms that the Father is the cause of the Son (cf. Edwards 2020, 73). The Father alone does not have a cause for His existence, whereas the Son is eternally caused by the Father. The causal relationship between the Father and Son is widely affirmed by theologians who are considered to be orthodox and heretical such as Origen, Arius, Athanasius, Gregory of Nazianzus, Gregory of Nyssa, Eunomius, and Augustine. In terms of developing an analytic approach to conciliar Trinitarian theology, the aetiological subordination of the Son is most certainly part of the conciliar deposit. As such, it is going to be included in how one articulates (T5).

The next kind of subordination is axiological subordination. Based on the comments from Edwards, I take it that axiological subordination is supposed to be something like the following.

Axiological Subordination: The Son is subordinate to the Father in that (a) the Son is equal to the Father in essence, but (b) is inferior in rank or status.

I find myself uncertain how the Son could be equal to the Father in essence but inferior in rank or status. Yet, as Edwards' essay demonstrates, this is a view that 
is affirmed by various thinkers in church history. I just find myself at a loss how to grasp the concept. To explain my confusion, consider the following. If the Son and Father are equal in essence, I take this to mean that the Son and Father are extensively and intensively equal. The Son and the Father have all of the greatmaking properties, and have all of the great-making properties to their maximal degree of intensity. I don't understand where an inferiority of rank or status can sneak into this picture. The only way that I can think to establish a subordination of rank or status would involve the Son being extensively or intensively inferior to the Father. In which case, the notion of axiological subordination would collapse into ontological subordination, but various theologians will wish to resist this collapse. Perhaps the idea is that the Son is of an inferior rank because He has a cause for His existence, and is caused to have the same essence as the Father. I gather that this is the basis for some theologians to claim that the Son is axiologically subordinate to the Father. In the next section, I shall raise my worries about this.

For now, I wish to move onto the economic subordination of the Son. This is another form of subordination that appears to have wide affirmation among orthodox and heretic alike. From what I understand, this fourth kind of subordination is unique from the others. The first three kinds of subordination refer to immanent, eternal, and essential relations between the Father and Son apart from the creation of the universe. For example, a Eunomian theologian will affirm the ontological and aetiological subordination of the Son by saying that the Father eternally causes the Son to eternally exist. ${ }^{4}$ Whereas a Nicene theologian will affirm only the aetiological subordination of the Son by saying that the Father eternally causes the Son to eternally exist. In the eyes of a Nicene theologian, this aetiological subordination is an eternal and essential relationship between the Son and Father that somehow does not entail ontological subordination.

Things are quite different with economic subordination. This fourth kind of subordination refers to a subordination relation that obtains after the creation of the universe, and within the economy of salvation. This kind of subordination is an accidental, or non-essential, relationship between the Father and the Son. This kind of subordination only obtains when the Son becomes incarnate. Hence, I define it as follows.

Economic Subordination: At some point in time, the Son became accidentally subordinate to the Father via the voluntary assumption of a human nature.

\footnotetext{
${ }^{4}$ For more on the thought of Eunomius, see Eunomius (1987).
} 


\section{R. T. MULLINS}

Again, I emphasize that the economic subordination is accidental and not an essential subordination relationship. This is so because God did not have to create a universe, nor did the Son have to become incarnate. In fact, a fairly traditional stance within Christian thought is that any of the divine persons could have become incarnate (cf. Cross 2002, 179). Hence, the incarnation is accidental and not essential to the Son.

With these different kinds of subordination relations identified, I can return to articulating the proper notion of subordination within (T5). What kind of subordination relation does conciliar Trinitarian thought have in view in (T5)? The answer seems to be aetiological subordination.

The Creed of Nicaea of 325 states that the Son was "begotten of the Father...begotten, not made." The Creed makes a distinction between 'begotten' on the one hand, and 'made' or 'created' on the other. The teaching of the Creed is that if the Son is begotten of the Father, He can be of the same essence as the Father. If the Son is made or created, He cannot be of the same essence as the Father. This relation of begottenness is a communication of the divine essence from the Father to the Son (Hasker 2013, 223). This is because the Father is the source, or fount, of divinity who causes the Son to be divine. ${ }^{5}$ The Father alone is the self-subsistent divinity by nature; God from no other source than Himself. It is the Son's derivation from the Father that causes the Son to exist and be divine (cf. Beeley 2012, 70-71).

It should be emphasized that the conciliar causal concept of 'begotten' at play in this creed is not metaphorical (Anatolios 2011, 190-191). Terms like 'begotten' and 'made' are both causal, but there is a slight difference that quickly became obscured in these early debates due, in part, to the similar spelling in the Greek. As Alasdair Heron explains, the term 'begotten' (Greek: gennetos) in the Creed is intended to denote "that which has a cause or source outside itself." This causal source could be a something, or in the case of the Trinity, someone. This need not involve the begotten thing coming into existence according to the Nicene theologians. The term 'created' or 'made' (Greek: genetos), however, is intended to denote "that which has come into being" (Heron 1981, 60-61). So the creedal teaching affirms that the Son is caused to exist by the Father, but in such a way that the Son never came into being. Whereas the Father alone is unbegotten/uncaused (Greek: agenetos/agennetos), and is the source and cause of the Trinity. ${ }^{6}$

This causal concept is not only contained in the Creed of Nicaea, it is also in the Niceno-Constantinopolitan Creed or Nicene Creed of 381. As Christopher Beeley points out, the Nicene Creed that is developed at the Council of

\footnotetext{
${ }^{5}$ Cf. Giles (2012, chapters 5-7); Beeley (2012, 90-93).

${ }^{6}$ Gregory of Nazianzus, The Theological Orations 3.3.
} 
Constantinople in 381 bears a close resemblance to the theology of Gregory of Nazianzus. This is understandable since Gregory was the presiding president of the Council (cf. Beeley 2012, 195-196). In Gregory's Trinitarian theology, the Father alone is the unoriginated or uncaused being. The Father eternally causes the Son to exist such that the Son is also eternal. Even though the Son is caused to exist, the Son does not begin to exist because the Son is begotten and not created. Since the Son is eternally begotten, the Son is co-eternal with the Father. ${ }^{7}$ Gregory's theology here is deeply traditional, and goes back at least to the Alexandrian traditions of Origen and Eusebius (cf. Beeley 2012, 23; 90-93). This is the understanding of 'eternally begotten' that is agreed upon by the Council of Constantinople, and written into the Nicene Creed. As Stephen Holmes makes clear, the claim is that "the Father is the personal cause of the Son," and because of this "they share the same nature" (Holmes 2012, 113).

The second ecumenical council at Constantinople in 381 not only affirms that the Father is the cause of the Son. It also extends this teaching to the Holy Spirit. The Nicaeno-Constantinopolitan Creed of 381 adds that the Holy Spirit proceeds from the Father. The idea here is that 'proceeds', like 'begotten', does not mean made or created. It is intended to be an affirmation that the Spirit is of the same essence as the Father and Son. 'Proceeds' with regard to the Holy Spirit functions metaphysically the same way as 'begotten' does. The Holy Spirit is caused to exist in such a way that the Holy Spirit never began to exist, but instead eternally exists.

When it comes to discerning the kind of subordination at play in (T5), the conciliar view is aetiological subordination. The Son and Holy Spirit are subordinate to the Father in that the Father is the cause for the Son and Holy Spirit. With this issue clarified, I turn to my final point of reflection on Edwards' essay. Is (T5) consistent with the minimal homoousios doctrine?

\section{Is Subordinationism a Heresy?}

Edwards' essay has quite the provocative title: "Is Subordinationism a Heresy?" If I understand Edwards' correctly, he is saying that certain kinds of subordination are perfectly in line with orthodox Trinitarian thought, whereas others are not. In particular, ontological subordination is ruled out by orthodoxy, whereas aetiological and economic subordination are affirmed by orthodoxy, with aetiological enjoying clear conciliar endorsement. As stated before, I am uncertain what to think about axiological subordination. In what follows, I wish to raise a worry for future work in analytic conciliar Trinitarian theology.

\footnotetext{
${ }^{7}$ Gregory of Nazianzus, The Theological Orations 3.3.
} 


\section{R. T. MULLINS}

The aetiological subordination of the Son will most likely be a contentious issue among contemporary analytic theologians. I have personally experienced a fair number of analytic thinkers refuse to believe that the aetiological subordination of the Son is the conciliar position. Yet there are analytic thinkers who are aware of the aetiological subordination of the Son, but they are split about the coherence of the Son's causal subordination with the homoousious doctrine. For example, several recent analytic theologians have offered critiques and defences of its coherency. William Lane Craig and I have argued that it is incoherent, whereas William Hasker and Mark Makin have sought to defend its coherency. ${ }^{8}$

By way of concluding my reflections on Edwards' paper, I shall develop two arguments for thinking that aetiological subordination is inconsistent with the homoousious doctrine.

\subsection{The Inconsistency Problem}

Call the first argument The Inconsistency Problem (IP) because it seeks to derive a contradiction from minimal homoousios, aetiological subordination, and fairly standard Christian claims about God. This argument starts by recalling the minimal homoousios doctrine.

IP1) Minimal Homoousios: The three divine persons are (i) extensively and intensively equal to each other, and (ii) extensively and intensively superior to all other beings.

From (IP1), the following can be inferred.

IP2) If the Father and Son are minimally homoousios, then the Father and Son are extensively equal to each other.

The next step of the argument is to assert the conciliar affirmation of the aetiological subordination of the Son.

IP3) Aetiological Subordination: The Son is subordinate to the Father in that the Son is caused to exist by the Father.

From here, the argument asserts that aseity is a great-making property, and thus essential for divinity. This is an uncontroversial assertion to make within Christian thought.

\footnotetext{
${ }^{8}$ Cf. Craig (2019), Hasker (2017), Makin (2018), Mullins (2017).
} 
IP4) Aseity $=_{\text {def. }}$ not having a cause for one's existence.

IP5) If aseity is a great-making property, then the Father and the Son both have aseity.

IP6) Aseity is a great-making property.

IP7) Thus, the Father and the Son both have aseity.

(IP4) is a very common understanding of the divine attribute of aseity. (IP5) is a plausible inference to make from (IP1) and (IP2). This is because if the Father has a great-making property that the Son lacks, then the Father and Son will not be extensively equal. (IP6) is widely affirmed in Christian thought, with aseity being a standard divine attribute listed in systematic theology textbooks. (IP7) follows from (IP5) and (IP6).

By simplification, one can derive the following from (IP7).

IP8) The Father has the property of aseity.

IP9) The Son has the property of aseity.

From (IP4), one can infer the following.

IP10) If $x$ has a cause of its existence, then $x$ does not have the property of aseity.

From premise (IP3), one can infer the following.

IP11) The Son has a cause for His existence.

From (IP10) and (IP11), one can derive

IP12) Thus, the Son does not have the property of aseity.

From (IP9) and (IP12), one can derive a contradiction.

IP13) The Son has the property of aseity and the Son does not have the property of aseity.

The Inconsistency Problem has derived a contradiction from minimal homoousios, aetiological subordination, and fairly standard Christian claims about aseity. In order to avoid the Inconsistency Problem, one will need to deny one of the premises in the argument. The most obvious candidate is the aetiological subordination in premise (IP3). However, if one is attempting to 


\section{R. T. MULLINS}

develop a conciliar Trinitarian theology, then one cannot deny (IP3). Perhaps, one can try to deny premise (IP1) by saying that I have articulated a deficient minimal understanding of the homoousios doctrine. I must confess that if (IP1) is false, then I have lost my grasp on the minimal requirements for homoousios.

The next candidate premise for rejection is (IP6), the claim that aseity is a great-making property. I suppose that a Trinitarian theologian can reject the assertion that aseity is a great-making property, but this will have some series consequences for ontological and cosmological arguments for the existence of God which often rely on some notion of aseity. It will also undermine standard arguments from aseity to divine simplicity. Hence, rejecting (IP6) comes at a cost.

\subsection{The Ontological Subordination Problem}

If this derived contradiction were not bad enough, one can also argue that the Son is ontologically subordinate to the Father. Recall that ontological subordination involves the Son having an inferior essence to that of the Father. Call this the Ontological Subordination Problem (OSP). Like the previous argument, this argument will assume minimal homoousios and aetiological subordination.

OSP1) If the Father and Son are minimally homoousios, then the Father and Son are extensively equal to each other.

OSP2) Aetiological Subordination: The Son is subordinate to the Father in that the Son is caused to exist by the Father.

Upon reflection of ontological subordination, the following is a natural inference to make.

OSP3) If the Son lacks an essential great-making property that the Father has, then the Son has an extensively inferior essence to the Father.

OSP4) If the Son has an extensively inferior essence to the Father, then the Son is ontologically subordinate to the Father.

In the next stage of the argument, one asserts that aseity is a property that the Father has and that the Son lacks.

OSP5) The Father has the property of aseity.

OSP6) The Son lacks the property of aseity.

(OSP5) and (OSP6) gain justification from within conciliar Trinitarian theology. As noted above, the Nicene Creed explicitly states that the Father is an 
uncaused being, whereas the Son is caused to exist by the Father. This is captured by premise (OSP2) of the argument.

The next step in the argument is to assert that aseity is a great-making property. As noted above, aseity is widely regarded as a great-making property within natural theological arguments and Christian theology textbooks. So the assertion is incredibly plausible for a Christian to make.

OSP7) Aseity is a great-making property.

From (OSP5), (OSP6), and (OSP7), one can infer the following.

OSP8) The Son lacks an essential great-making property that the Father has.

From (OSP8) and (OSP3), one derives

OSP9) The Son has an extensively inferior essence to the Father.

From (OSP9) and (OSP4), one can derive

OSP10) The Son is ontologically subordinate to the Father.

As with the Inconsistency Problem, one will need to avoid the Ontological Subordination Problem by denying one of its premises. If one is attempting to develop a conciliar Trinitarian theology, premises (OSP1), (OSP2), (OSP5), and (OSP6) cannot be plausibly denied.

Of course, one strategy might be to reject (OSP6). There is precedent from within Reformed theology to assert that the Son is caused to have the property of aseity by the Father (cf. Webster 2008, 116). However, I find it implausible to suggest that the Son can be caused to exist and still somehow exist without a cause. That sounds incoherent from the start, so I suggest that one look elsewhere for a way to avoid the Ontological Subordination Problem.

One might try to reject (OSP3) and (OSP4) by saying that these premises are not natural interpretations of ontological subordination. If one wishes to make this strategy to avoid the argument, I should like to see what a more natural interpretation of ontological subordination looks like. This is not to say that there is no other natural interpretation of ontological subordination. It is simply a call for clarity on the exact understanding of ontological subordination.

Another strategy for avoiding the Ontological Subordination Problem is to reject (OSP7). However, as I have stated before, aseity is widely regarded by 


\section{R. T. MULLINS}

Christians as a great-making property that is essential for divinity. A Trinitarian is free to reject this assertion if she likes, but as I noted before, it comes at a cost.

\section{Conclusion}

Once again, I would like to thank Edwards for offering an intellectually stimulating paper on the different notions of subordination within Trinitarian thought. I think that clarifying the different kinds of subordination is helpful for the future of conciliar approaches to Trinitarian theology. I hope that my analytic reflections on Edwards' paper can help bring further clarity and intellectual rigor to the unfinished task of Trinitarian theorizing.

\section{Bibliography}

Anatolios, Khaled. 2011. Retrieving Nicaea: The Development and Meaning of Trinitarian Doctrine. Grand Rapids: Baker Academic.

Beeley, Christopher A. 2012. The Unity of Christ: Continuity and Conflict in Patristic Tradition. New Haven: Yale University Press.

Craig, William Lane. 2019 "Is God the Son Begotten in His Divine Nature?" TheoLogica: An International Journal for Philosophy of Religion and Philosophical Theology 3, 1: 22-32. https://doi.org/10.14428/thl.v2i3.16583.

Cross, Richard. 2002. The Metaphysics of the Incarnation: Thomas Aquinas to Duns Scotus. Oxford: Oxford University Press. https://doi.org/10.1093/acprof:oso/9780199244362.001.0001.

Edwards, Mark. 2020. "Is Subordinationism a Heresy?" TheoLogica: An International Journal for Philosophy of Religion and Philosophical Theology 4, 2: 6986. https://doi.org/10.14428/thl.v4i2.23803.

Eunomius. 1987. Eunomius: The Extent Texts. Translated by Richard Paul Vaggione. New York: Oxford University Press.

Giles, Kevin N. 2012. The Eternal Generation of the Son: Maintaining Orthodoxy in Trinitarian Theology. Downers Grove: InterVarsity Press.

Hasker, William. 2017. "God's Only Begotten Son: A Reply to R.T. Mullins." European Journal for Philosophy of Religion 9: 217-237. https://doi.org/10.24204/ejpr.v9i4.1942.

Hasker, William. 2013. Metaphysics and the Tri-Personal God. Oxford: Oxford University Press.

Heron, Alasdair I. 1981. "Homoousios with the Father." In The Incarnation: Ecumenical Studies in Nicene-Constantinopolitan Creed A.D. 381, edited by Thomas F. Torrance. Edinburgh: Handsel.

Holmes, Stephen. 2012. The Quest for the Trinity: The Doctrine of God in Scripture, History and Modernity. Downers Grove: InterVarsity Press. 
Leftow, Brian. 2011. "Why Perfect Being Theology?" International Journal for Philosophy of Religion, 69: 103-118. https://doi.org/10.1007/s11153-010-9267-0.

Makin, Mark. 2018. "God from God: The Essential Dependence Model of Eternal Generation." Religious Studies $\quad$ 54: 377-394. https://doi.org/10.1017/S0034412518000197.

McCall, Thomas, and Michael C. Rea. 2009. Philosophical and Theological Essays on the Trinity. Oxford: Oxford University Press. https://doi.org/10.1093/acprof:oso/9780199216215.001.0001.

Mullins, R.T. "Hasker on The Divine Processions of the Trinitarian Persons." European Journal for Philosophy of Religion 9: 181-216. https://doi.org/10.24204/ejpr.v9i3.1941.

Nagasawa, Yujin. 2017. Maximal God: A New Defense of Perfect Being Theism. Oxford: Oxford University Press. https://doi.org/10.1093/oso/9780198758686.001.0001.

Richards, Jay Wesley. 2003. The Untamed God: A Philosophical Exploration of Divine Perfection, Simplicity, and Immutability. Downers Grove: InterVarsity Press.

Rogers, Katherin A. 2000. Perfect Being Theology. Edinburgh: Edinburgh University Press.

Rogers, Katherin, and William Hasker. 2011. "Anselm and the Classical Idea of God: A Debate." In Philosophy of Religion: The Key Thinkers, edited by Jeffrey J. Jordan. London: Continuum International Publishing Group.

Sexton, Jason, 2014. Two Views on the Doctrine of the Trinity. Grand Rapids: Zondervan.

Speaks, Jeff. 2018. The Greatest Possible Being. Oxford: Oxford University Press. https://doi.org/10.1093/oso/9780198826811.001.0001.

Webster, John. 2008. "Life in and of Himself: Reflections on God's Aseity." In Engaging the Doctrine of God: Contemporary Protestant Perspectives, edited by Bruce L. McCormack. Edinburgh: Rutherford House.

Wierenga, Edward. 2011. "Augustinian Perfect Being Theology and the God of Abraham, Isaac, and Jacob." International Journal for Philosophy of Religion 69: 139-151. https://doi.org/10.1007/s11153-010-9270-5.

Published Online: February 10, 2020 